\title{
N86-19909 851393 \\ CELSS Experiment Model and Design \\ Concept of Gas Recycle System
}

\author{
Keiji Nitta \\ and Mitsuo Oguchi \\ National Aerospace Laboratory \\ Tokyo, Japan \\ Syuji Kanda
}

Submarıne Desıgnıng Department

Kawasakı Heavy Industries Ltd

\section{ABSTRACT}

In order to prolong the duration of manned missions around the earth and to expand the human existing region from the earth to other planets such as a Lunar Base or a manned Mars flight mission, the CELSS becomes an essential factor of the future technology to be developed through utilization of Space Station.

The preliminary SE\&I (System Engineering and Integration) efforts regarding CELSS have been carried out by the Japanese CELSS concept study group for clarifying the feasibility of hardware development for space station Experiments and for getting the time phased mission sets after Fy 1992 . The results of these studies are breifly summarized and thereafter, the design and utilization methods of a Gas Recycle System for CELSS experiments are discussed.

\section{PROPOSED EXPERIMENTS AND ITS MISSION ANALYSIS}

According to NASA's call for international participation in the space Station program, data sources for Space Station Utilization concepts in many fields have been collected at the Japanese Space Station Symposium held in October 1982. Among the papers presented at this Symposium, eleven experiment proposals as shown in Table 1 related to CELSS have been extracted as the data source for CELSS mission analysis. Using these data sources, extensive study for clarifying the development feasibility of hardware necessary to conduct the CELSS experiments with state of art equipment have been conducted.

Each proposed theme was divided into the research items closely connected with experiment hardware and the necessary time spans for developing hardware were investigated considering the technological maturity and effectiveness for experiments. Table 2 shows
Kobe, Japan the strawman CELSS experiment concept and is described in next section.

\section{CELSS EXPERIMENT CONCEPT}

The CELSS is the technology for making a stable ecology among animals and plants without re-supply of materials and using a special controlled environment. Therefore the CELSS would be divided into two sections; the environmental control section and the cultivating and breeding section of plants and animals. In the environment control section, at least three major systems, shown Fig. 1, should be installed for sustaining the gas environment, for water recycle and for decomposing waste materials into a fertilizer solution.

In the cultivating and breeding section, the Algae and higher plant cultivation systems for converting carbon dioxide to oxygen and for producing food are to be installed. In addition aminal and fish breeding systems for obtaining animal protein should also be installed.

In order to develop CELSS technology, it is necessary to take a long time span as described in previous section because basic ground based experiments related to the CELSS are required before developing the flight experiment hardware, and also because the data of stabilities about the morphogenesis and physiology of the higher plants and algae in space environment have not been fully accumulated at the present time.

Based on the above considerations, the time phased mission sets for utilizing the space station were determined as a Japanese strawman CELSS mission mode1. (Reference 1) (Nitta, 1984)

According to this mission model, the first time mission is to be conducted during 1992 - 1995 for evaluating the higher plant and algae cultivation methods and for summing up the available data about the stability of 
Table 1 Proposed Theme

\begin{tabular}{|c|c|c|}
\hline No. & Theme & Description of Content \\
\hline EL-01 & Agricultural Laboratory in Space & $\begin{array}{l}\text { Fungi production for cellulose decomposition, } \\
\text { animal and fish breeding for food production, } \\
\text { higher plant and algae plantation for food } \\
\text { production and gas conversion, salt accumula- } \\
\text { tion plant for sodium chloride extraction, } \\
\text { hydrophyte planting for nitrogen fixation, } \\
\text { methanogen fermentation for waste management } \\
\text { and construct the closed ecology with bio } \\
\text { species mentioned above. }\end{array}$ \\
\hline EL -02 & Space Agriculture Experiment & $\begin{array}{l}\text { Vegetable planting for food production and } \\
\text { gas conversion. Solar light supply system for } \\
\text { photosynthetic reaction of vegetable. }\end{array}$ \\
\hline EL-03 & $\begin{array}{l}\text { Study on Space Agriculture and } \\
\text { Closed Ecological Life Support } \\
\text { System }\end{array}$ & $\begin{array}{l}\text { Gas recycle system for stabilizing gas } \\
\text { environment, water recycle system for suppling } \\
\text { the necessary water, wet oxidation system for } \\
\text { waste management, higher plant and algae } \\
\text { cultivator for food production and gas conver- } \\
\text { sion, physico-chemical sodium extraction } \\
\text { system, and low gravity generator for testing } \\
\text { geotropism. }\end{array}$ \\
\hline EL-04 & Non-Gravity Plant Experiment System & $\begin{array}{l}\text { Chetotaxis experiment in } 0 G \text {. Organella growth } \\
\text { experiment in } O G \text { and geotropism experiment of } \\
\text { higher plant. }\end{array}$ \\
\hline EL-05 & $\begin{array}{l}\text { Project for establishments of } \\
\text { Breeding and Management System of } \\
\text { several Higher Animals under Space } \\
\text { Environment }\end{array}$ & $\begin{array}{l}\text { Reproduction, growth, enbryogenesis and gene- } \\
\text { tics experiment in OG using Mouse, Quail and } \\
\text { Tilapia, and breeding technology development } \\
\text { for future food production. }\end{array}$ \\
\hline EL-06 & $\begin{array}{l}\text { Micro-Ecological System in Space } \\
\text { Station }\end{array}$ & $\begin{array}{l}\text { Gas recycle system, water recycle system and } \\
\text { incineration waste management system are } \\
\text { recommended. }\end{array}$ \\
\hline EL-07 & $\begin{array}{l}\text { Microbial Fermentor in very low } \\
\text { gravitational force }\end{array}$ & $\begin{array}{l}\text { Space-use fermentor design for practical use } \\
\text { of microbes in environment control. }\end{array}$ \\
\hline EL-08 & $\begin{array}{l}\text { Field of Plant Research in Space } \\
\text { Station }\end{array}$ & $\begin{array}{l}\text { Cell culture, pathogen study and protein rich } \\
\text { flour separation using } O G \text {. }\end{array}$ \\
\hline $\mathrm{EL}-09$ & Plant Experiment Subsystem & Plant cultivator, phytotron design. \\
\hline EL-10 & $\begin{array}{l}\text { Biochemical Studies on elementary } \\
\text { cycles in a Closed Ecosystem }\end{array}$ & $\begin{array}{l}\text { Simple ecosystem and immobilized enzyme } \\
\text { bio-reactor for supplementary food production. }\end{array}$ \\
\hline EL-11 & $\begin{array}{l}\text { Space Station with an Artificial } \\
\text { Gravity }\end{array}$ & $\begin{array}{l}\text { Large scale ecological life support experiment } \\
\text { station. }\end{array}$ \\
\hline
\end{tabular}


Table 2

Proposed Research Items

\begin{tabular}{|c|c|c|c|c|c|}
\hline $\begin{array}{l}\text { Exp. } \\
\text { No }\end{array}$ & Items contained & $\begin{array}{c}1991 \\
\sim 1994\end{array}$ & $\begin{array}{l}1995 \\
\sim 1998\end{array}$ & 1999 & Reasons \\
\hline EL-01 & $\begin{array}{l}\text { ( 1) Higher plant for food } \\
\text { ( 2) Microbial waste management } \\
\text { ( 3) Sodium accum. plant } \\
\text { ( 4) Hydrophyte for fertilizer } \\
\text { ( 5) Fish and Animal } \\
\text { ( 6) Fungus } \\
\text { ( 7) Integrated ecological test }\end{array}$ & , & $\mathrm{V}$ & $\begin{array}{l}\text { V } \\
\text { V } \\
\text { V }\end{array}$ & $\begin{array}{l}\text { Essentially required for CELSS } \\
\text { After the sludge problem is } \\
\text { solved } \\
\text { Easy to conduct with phytotron } \\
\text { After the effectiveness is } \\
\text { examined } \\
\text { Essential for animal protein } \\
\text { After the effectiveness is } \\
\text { examined } \\
\text { Possible if physico-chemical } \\
\text { systems introduced }\end{array}$ \\
\hline EL-02 & $\begin{array}{l}\text { ( 1) Experiment module } \\
\text { (2) Solar collector system } \\
\text { ( 3) Vegetable for foods }\end{array}$ & $\begin{array}{l}\mathrm{V} \\
\mathrm{V}\end{array}$ & $\begin{array}{l}\mathrm{V} \\
\mathrm{V} \\
\mathrm{V}\end{array}$ & & $\begin{array}{l}\text { Dedicated mission } \\
\text { Required for higher plant } \\
\text { Same as EL-01 (1) }\end{array}$ \\
\hline EL-03 & $\begin{array}{l}\text { ( 1) Experiment module } \\
\text { ( 2) Animal and Fish } \\
\text { ( 3) Gas separation and reservoir } \\
\text { ( 4) Higher plant for foods } \\
\text { ( 5) Algae for gas exchange } \\
\text { ( 6) Food preparation } \\
(\text { 7) Wet oxidation was te manage. } \\
\text { ( 8) Physico-chemical sodium extract. } \\
\text { ( 9) Nutrient chemical product. } \\
\text { (10) Low-G generator }\end{array}$ & $\begin{array}{l}\text { V } \\
\text { V }\end{array}$ & $\begin{array}{l}\mathrm{V} \\
\mathrm{V} \\
\mathrm{V} \\
\mathrm{V} \\
\mathrm{V} \\
\mathrm{V} \\
\mathrm{V} \\
\mathrm{V} \\
\mathrm{V}\end{array}$ & $\begin{array}{l}\mathrm{V} \\
\mathrm{V} \\
\mathrm{V} \\
\mathrm{V} \\
\mathrm{V} \\
\mathrm{V} \\
\mathrm{V} \\
\mathrm{V}\end{array}$ & $\begin{array}{l}\text { Same as EL-02 ( } 1 \text { ) } \\
\text { Same as EL-01 ( } 5 \text { ) } \\
\text { Essential for eco-stabilization } \\
\text { Same as EL-01 (1) } \\
\text { Essential for gas conversion } \\
\text { After eco-system established } \\
\text { Essential for eco-stabilities } \\
\text { Easily obtained with water } \\
\text { recycle system } \\
\text { Easily obtained with wet } \\
\text { oxidation method } \\
\text { Essential for testing gravity } \\
\text { effect }\end{array}$ \\
\hline EL-04 & $\begin{array}{l}\text { ( 1) Chetotaxis } \\
\text { ( 2) Organella } \\
\text { ( 3) Geotropism of plant }\end{array}$ & $\mathrm{V}$ & $\begin{array}{l}\mathrm{V} \\
\mathrm{V}\end{array}$ & $\mathrm{V}$ & $\begin{array}{l}\text { After feasibility study is } \\
\text { conducted } \\
\text { Same as above } \\
\text { Essential for plantation }\end{array}$ \\
\hline $\mathrm{EL}-05$ & ( 1) Fish and Animal production & & $\mathrm{V}$ & $\mathrm{v}$ & Same as EL-01 (5) \\
\hline$E L-06$ & $\begin{array}{l}\text { ( 1) Higher plant for foods } \\
\text { ( 2) Algae for efficient gas exchange } \\
\text { ( 3) Incineration waste management } \\
\text { ( 4) Physico-chemical sodium extract. } \\
\text { ( 5) Nutrient chemical production }\end{array}$ & $\begin{array}{l}\mathrm{V} \\
\mathrm{V}\end{array}$ & $\begin{array}{l}\mathrm{V} \\
\mathrm{V} \\
\mathrm{V} \\
\mathrm{V}\end{array}$ & $\begin{array}{l}\mathrm{V} \\
\mathrm{V} \\
\mathrm{V}\end{array}$ & $\begin{array}{l}\text { Same as EL-01 (1) } \\
\text { Same as EL-03 (5) } \\
\text { After feasibility is studied } \\
\text { Same as EL-03 (8) } \\
\text { Same as EL-03 (9) }\end{array}$ \\
\hline$E L-07$ & ( 1) Fermentor & & & $\mathrm{V}$ & Same as $E L-01$ (2) \\
\hline $\mathrm{EL}-08$ & $\begin{array}{l}\text { ( 1) Cell culture } \\
\text { ( 2) Pathogen } \\
\text { ( 3) Protein rich flour separ. }\end{array}$ & $\mathrm{v}$ & & V & $\begin{array}{l}\text { After feasibility is studied } \\
\text { Necessary to grow the } \\
\text { bio-species } \\
\text { After feasibility is studied }\end{array}$ \\
\hline EL-09 & ( 1) Plant cultivator & $\mathrm{v}$ & $\mathrm{V}$ & & Essential for plantation \\
\hline$E L-10$ & ( 1) Bioreactor for food product. & & & $\mathrm{V}$ & $\begin{array}{l}\text { After technology is } \\
\text { established }\end{array}$ \\
\hline$E L-11$ & ( 1) Future experiment module & & & V & Future concept \\
\hline
\end{tabular}


$\because$

$\therefore$

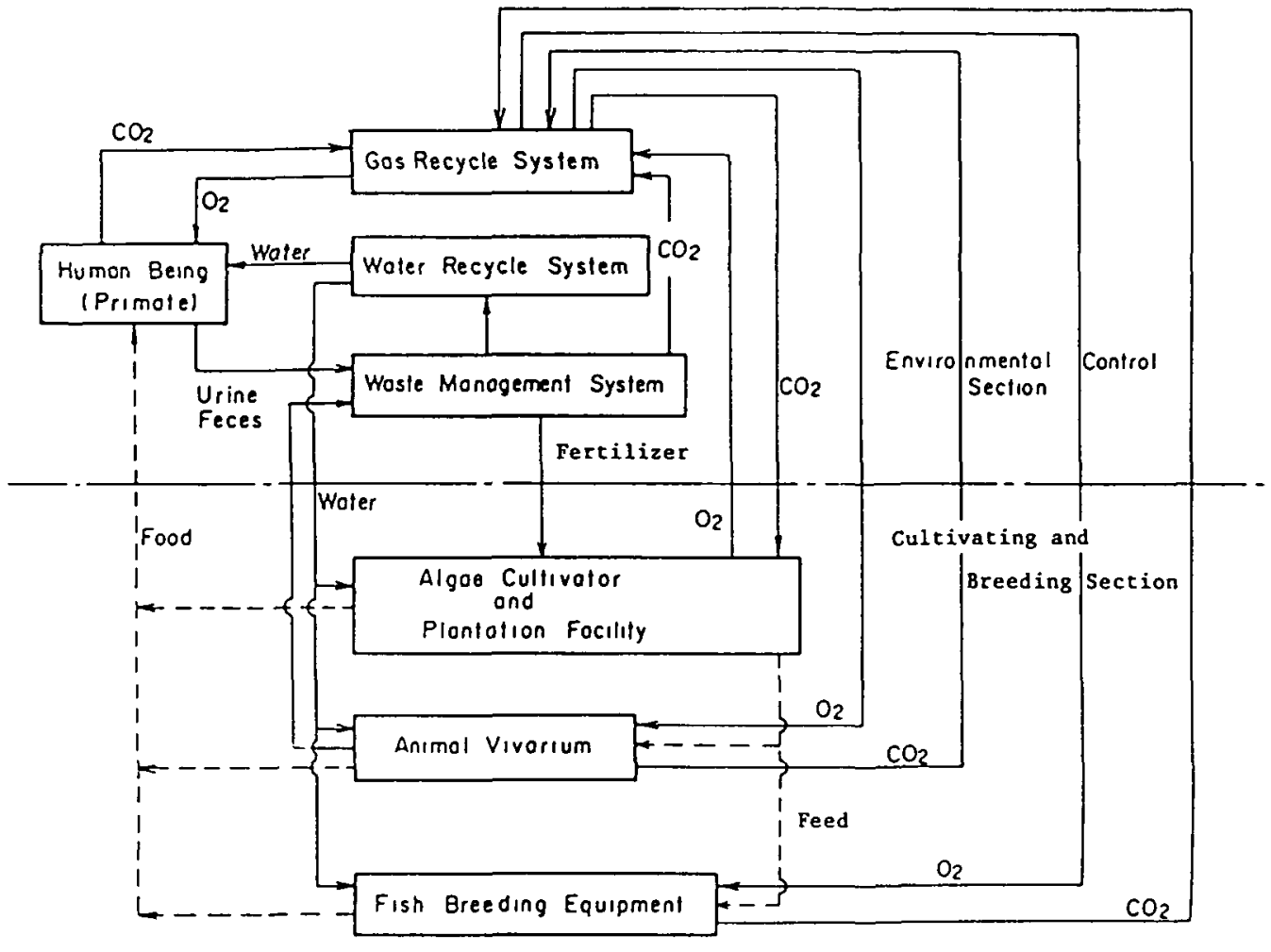

Fig. 1

\section{CELSS Concept}

photosynthesis and the possibility of propagation under the $O-G$ environment in Manned Space Station.

The second time phased mission which constitutes the dedicated mission is to be conducted during 1995 - 1998 for checking the possibility of a micro closed-ecology system using animals and $f$ ish instead of human beings, and the testings and evaluation of the non-biological system performance such as the gas recycle system, the water recycle system and the wet oxidation waste management system. Artificial gravity effects on the biological system are also to be evaluated.

In the last time phased mission, the main food supply and gas conversion from carbon dioxide to oxygen for a one man crew support are to be tested using the photosynthetic reaction of the plant and algae and the necessary animal protein production systems are to be evaluated using small animals and fish.

The experiment architectures for each mission are shown in Fig. 2. Due to this mission model, the preliminary design of all hardware necessary to conduct each time phased experiments and the investigation of integration methods to the space station have been studied and reported as shown in references 2,3 .

\section{FUNCTIONS OF GAS RECYCLE SYSTEM}

The appropriate quantities of oxygen, food and water should be continuously supplied for human beings and animals, and carbon dioxide and waste materials such as urine and feces should be taken away.

Both the oxygen and food necessary to animals, including human beings, are originally generated from the photosynthetic reaction of plants and algae using carbon dioxide and solar light. The carbon dioxide concentration on the earth is stabilized by the function of atmospheric circulation and the gas reservior function of sea-water. This $0.03 \% \mathrm{CO}_{2}$ concentration is not always appropriate for plant growth and it seems preferable to use higher concentrations, $0.3 \%$ and so on, for obtaining maximum growth rate. Therefore, the Gas Recycle System to be used in CELSS experiments has to have the ability to supply different $\mathrm{CO}_{2}$ concentrations to the cabin and animal vivarium and the phytotron or higher plant cultivator.

In other words, the Gas Recycle System should have the following functions,

(1) to separate carbon dioxide and oxygen within the atmosphere provided from the cabin, the animal vivarium and/or the phytotron individually,

(2) to compress the separated gases such that carbon dioxide, oxygen and nitrogen can be stored in high pressure bottles,

(3) to release and supply the appropriate gases to the cabin, the animal vivarium and the phytotron individually through gas regulator manifolds. 


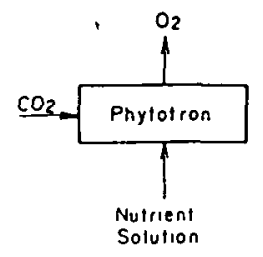

First Phose Experinent Concept

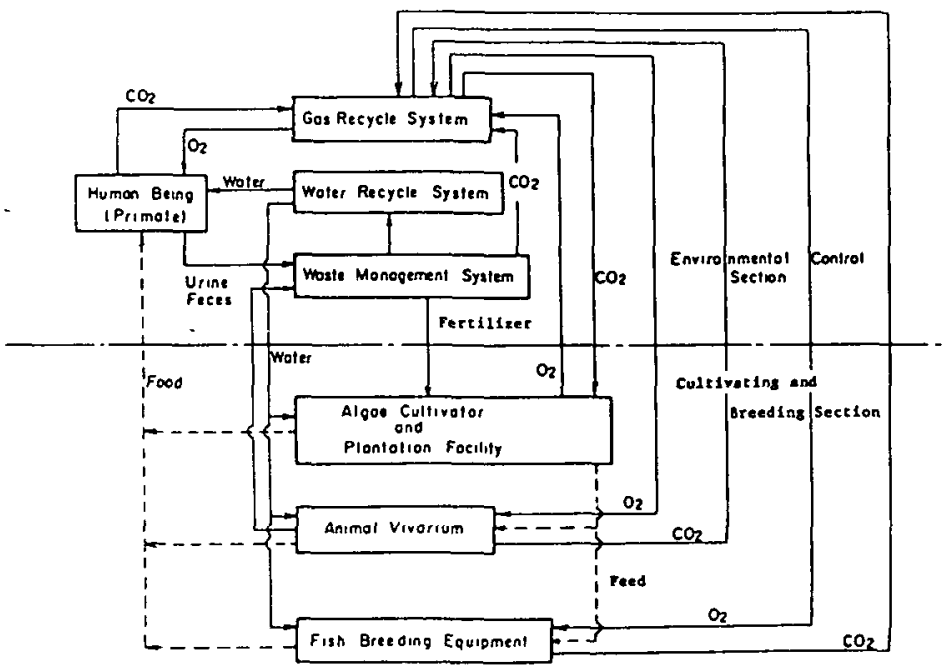

Thuro Phose Experiment Concept

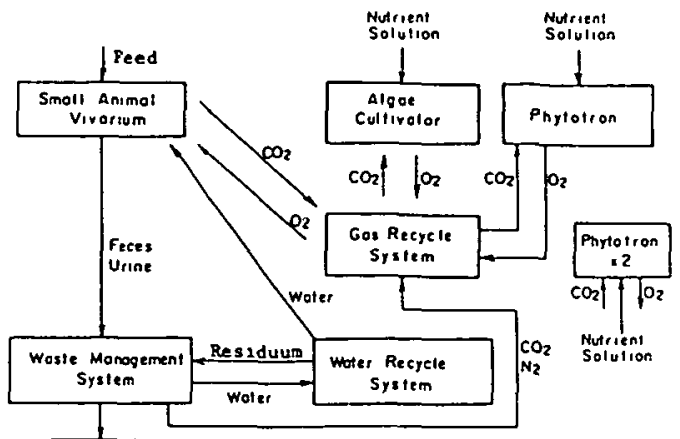

Fig. 2 Experiment Architectures of Each Mission

\section{REQUIREMENTS FOR GAS RECYCLE SYSTEM}

The various methods for separating each gas have been proposed and studied. (Reference 4-16)

Carbon dioxide gas separation, has typically used three methods, the molecular sieve, the hydrogen polarized cell and chemical absorption and desorption methods. Each has been discussed for application to CELSS experiments.

The molecular sieve method seems to be most reliable and has been used in skylab, however dehumidification and the precise temperature and pressure control required for constructing the system using this method, would become more complicated. The hydrogen polarized cell method requires hydrogen to concentrate carbon dioxide, again the separation of hydrogen gas from the resultant gas and reduction of hydrogen gas are required.

The chemical absorption and desorption method seems to become more important since solid amine has been developed because of its regenerable and simple characteristics instead of LiOH, and the various applications are now being considered for use in the environmental control system in Space Station.

Therefore, based on this matter, this chemical method using the solid amine looks to be more preferable for adoption to the CELSS experiment hardwares.

As for the oxygen gas separation, three typical methods has been developed and used for various applications. One is again the molecular sieve method which has the same defect as mentioned above.

The second is the chemical absorption and desorption method using complex salt. This method has already been applied to testing the atmospheric control of the submarine and to the oxygen supply system for $B-1$ bomber, and this method is again preferable for being adopted to the CELSS experiment hardwares because of its simple characteristics.

The third one is the zirconia oxygen pumping method in which zirconia is used as a solid electrolyte for oxygen separation, this method also has simple characteristics and is preferable for being adopted to the CELSS experiment hardwares.

The gas recycle system capability to be designed has been assumed for supporting the respiration of a one man crew where the oxygen consumption per man-day is about 925 g/day and the carbon dioxide exhaust per man-day is about $1,130 \mathrm{~g} /$ day, corresponding to $301 \mathrm{it} . / \mathrm{hr}$. of oxygen and $251 \mathrm{it} . / \mathrm{hr}$. of carbon dioxide.

Therefore, the Gas Recycle System to be used in the CELSS experiments has to have the ability to supply these quantities of each gas. 


\section{DESIGN CONCEPT OF GAS RECYCLE SYSTEM}

Fig. 3 shows the gas recycle sytstem functional diagram. Inlet gas is a mixture of $\mathrm{O}_{2}$ (Oxygen), $\mathrm{N}_{2}$ (Nitrogen), $\mathrm{CO}_{2}$ (Carbon droxide) and various trace contaminants.

At the filter, trace, contaminants are removed.

$\mathrm{CO}_{2}$ is separated and concentrated by a regenerable $\mathrm{CO}_{2}$ absorber, and then, compressed and stored into the $\mathrm{CO}_{2}$ gas bottle.

$\mathrm{O}_{2}$ is also separated and concentrated by a regenerable $o_{2}$ concentrator, and, compressed and stored into the $\mathrm{O}_{2}$ gas bottle.

Thus, inlet gas is separated and concentrated into $\mathrm{CO}_{2}, \mathrm{O}_{2}$ and $\mathrm{N}_{2}$ gases.

Then, these gases are mixed properly and supplied to various utilities.

\section{GAS ABSORPTION AND DESORPTION}

In the gas recycle system, there are $\mathrm{CO}$ and $\mathrm{O}_{2}$ concentration processes. These are accomplished by two gas absorption and desorption processes, one is $\mathrm{CO}_{2}$ absorption and desorption process using Solid Amine, and the other is $\mathrm{O}_{2}$ absorption and desorption processes using Salcomine.

\section{$6.1 \mathrm{CO}_{2}$ Absorption and Desorption Process}

$\mathrm{CO}_{2}^{2}$ absorption and desorption is generally acomplished by using various kinds of amines, the chemical reaction could be described as shown below.

The solution of Ethanol Amine, such as Mono Ethanol Amine (MEA) and/or Diethano1 Amine (DEA) absorbs $\mathrm{CO}_{2}$ at the normal temperature and desorbs ${ }^{2} \mathrm{CO}_{2}$ at the high temperature, as indicated by the following reaction equation.

$$
\mathrm{RR}^{\prime} \mathrm{NH}+\mathrm{H}_{2} \mathrm{O}+\mathrm{CO}_{2} \underset{\text { (high temp.) }}{\stackrel{\text { (normal temp.) }}{\stackrel{\text { (high }}{\leftrightarrows}}} \mathrm{RR}^{\prime} \mathrm{NH}_{2} \mathrm{CO}_{3}
$$

where $\mathrm{R}=\mathrm{HOCH}_{2} \mathrm{CH}_{2}, \mathrm{R}^{\prime}=\mathrm{H}$, for $\mathrm{MEA}$

$$
\mathrm{R}=\mathrm{R}^{\prime}={ }^{2} \mathrm{HOCH}_{2} \mathrm{CH}_{2} \text {, for } \mathrm{DEA}
$$

This reaction has been directly applied to the $\mathrm{CO}_{2}$ scrubbing unit in submarines. However, in ${ }^{2}$ space craft under the microgravity environment, such chemical agents seem not to be appropriate because of the difficulties of the gas and liquid separation.

Therefore, the solidification method of the amine: has been studied and developed. Solid Amine consists of micro porous beads whose surface are coated with an amine. The substrate of beads is composed of a polymeric acrylic ester. (Reference 17,18)

Fig. 4 shows the $\mathrm{CO}_{2}$ separating and concentrating system diagram. In this system, Solid Amine absorbes $\mathrm{CO}_{2}$ at the normal temperature, and outlet gas from the solid amine canister is $\mathrm{CO}_{2}$ lean gas.

Part of the $\mathrm{CO}_{2}$ lean outlet gas flow returns to the cabin atmosphere, and the residual part of the flow is led to the next process.

When one canister becomes saturated with $\mathrm{CO}_{2}$, the inlet flow is switched to the other canister and $\mathrm{CO}_{2}$ absorption is continued in the new canister. The $\mathrm{CO}_{2}$ saturated Solid Amine canister is heated and desorbs the $\mathrm{CO}_{2}$. This $\mathrm{CO}_{2}$ gas is led to the $\mathrm{CO}_{2}$ compressor to be compressed and stored.

These Solid Amine canisters are used as absorbing, desorbing and precooling, respectively, and by the combination of canister cooling and heating, continuous $\mathrm{CO}_{2}$ separation and concentration can be accomplished.

$6.20_{2}$ Absorption and Desorption

The $\mathrm{O}_{2}$ absorption and desorption process is carried out using Salcomine. Salcomine (Bis(3-ethoxy salicyl aldehyde) ethylene diamine cobalt(II) - Fig. 5) absorbes $0_{2}$ at normal temperature and desorbes $\mathrm{O}_{2}$ at ${ }^{2}$ the high temperature. (Reference 1)

Fig. 6 shows the $\mathrm{O}_{2}$ separating and concentrating system diagram.

In this system, $\mathrm{O}_{2}$ is absorbed into the Salcomine and $\mathrm{N}_{2}$ gas comes out of the

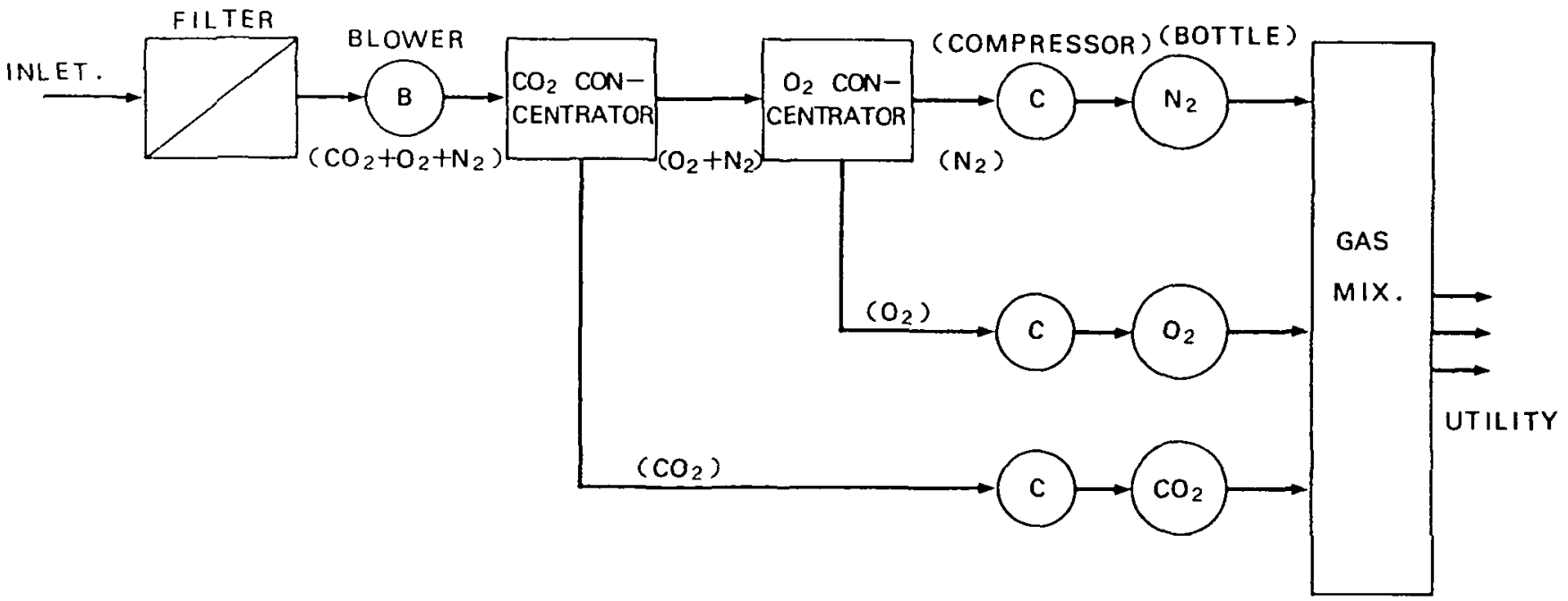

FIg 3 GAS RECYCLE SYSTEM FUNCTIONAL DIAGRAM 


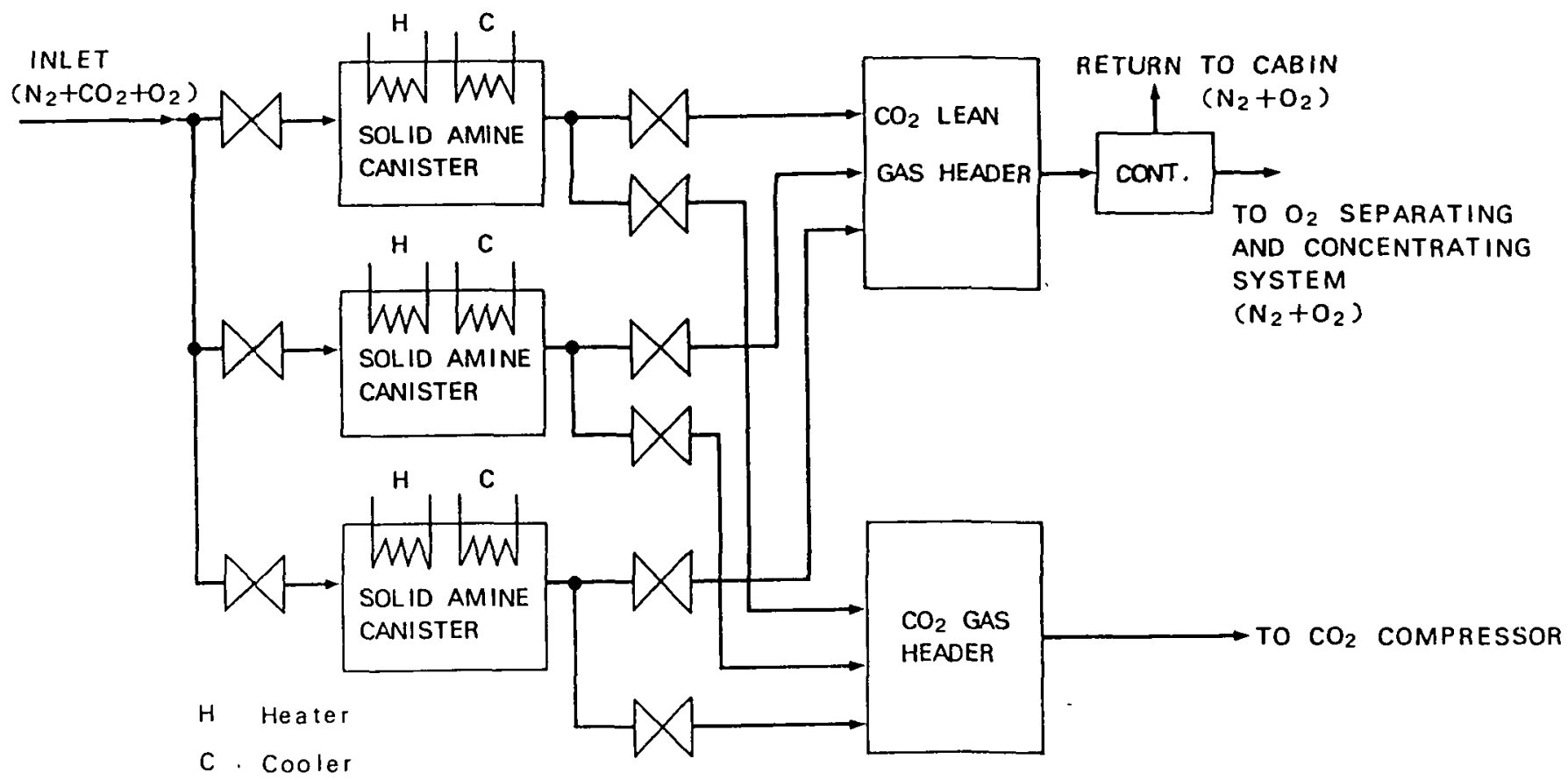

\section{Fig $4 \mathrm{CO}_{2}$ SEPARATING AND CONCENTRATING SYSTEM DIAGRAM}

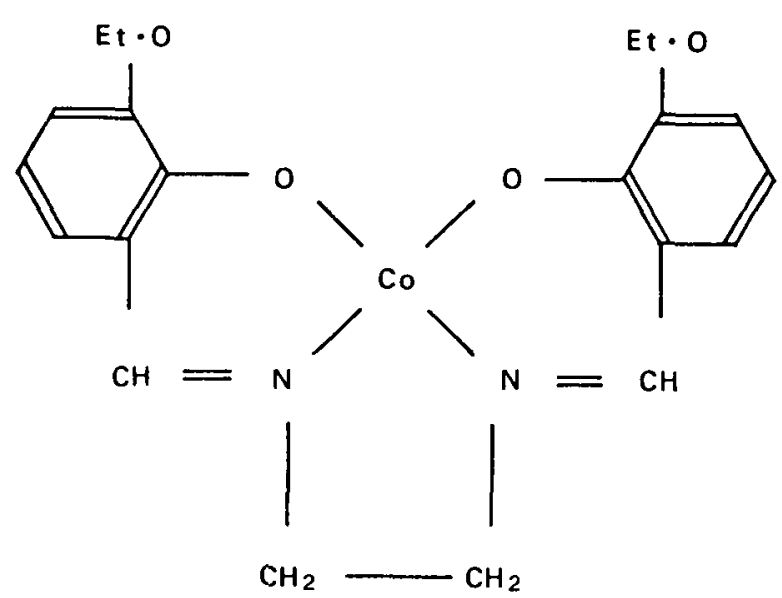

Fig 5 SALCOMINE canister outlet. This outlet $N_{2}$ gas is led to the compressor to be compressed and stored.

When the Salcomine canister becomes saturated the absorption cycle is terminated and the desorption cycle is started, in this desorption cycle this canister is heated and desorbs $\mathrm{O}_{2}$ gas. This $\mathrm{O}_{2}$ gas is led to the gas compressor to be compressed and stored. Continuous $\mathrm{O}_{2}$ absorption and desorption is carried out by means of cooling and heating three canisters alternately.

\section{CONSIDERATION FOR DESIGN}

Various CELSS experiment equipment will be considered in the design of the Gas Recycle System.

Phytotron (Plant cultivator) and RAHF (Research Animal Holding Facility) so called, the animal vivarium are considered.

Fig. 7 shows an example of Gas Recycle System application to the Phytotron and RAHF. In the RAHF, $\mathrm{O}_{2}$ is consumed and $\mathrm{CO}_{2}$ is exhaled by the metabolism of animals. ${ }^{2}$ In Phytotron, $\mathrm{CO}_{2}$ is consumed and $\mathrm{O}_{2}$ is exhaled according to the photosynthetic ${ }^{2}$ reaction of plants.

For stabilizing the $\mathrm{O}_{2}$ and $\mathrm{CO}_{2}$ gas concentrations inside the ${ }^{2}$ RAHF, $\sigma_{2}^{2}$ is supplied from Gas Recycle System, and the $\mathrm{CO}_{2}$ is pulled-out through the ventilator, this vented gas is mixed with the gas from the phytotron and the resultant gas is circulated through the Gas Recycle System and $\mathrm{CO}_{2}$ is separated and stored for re-use. 


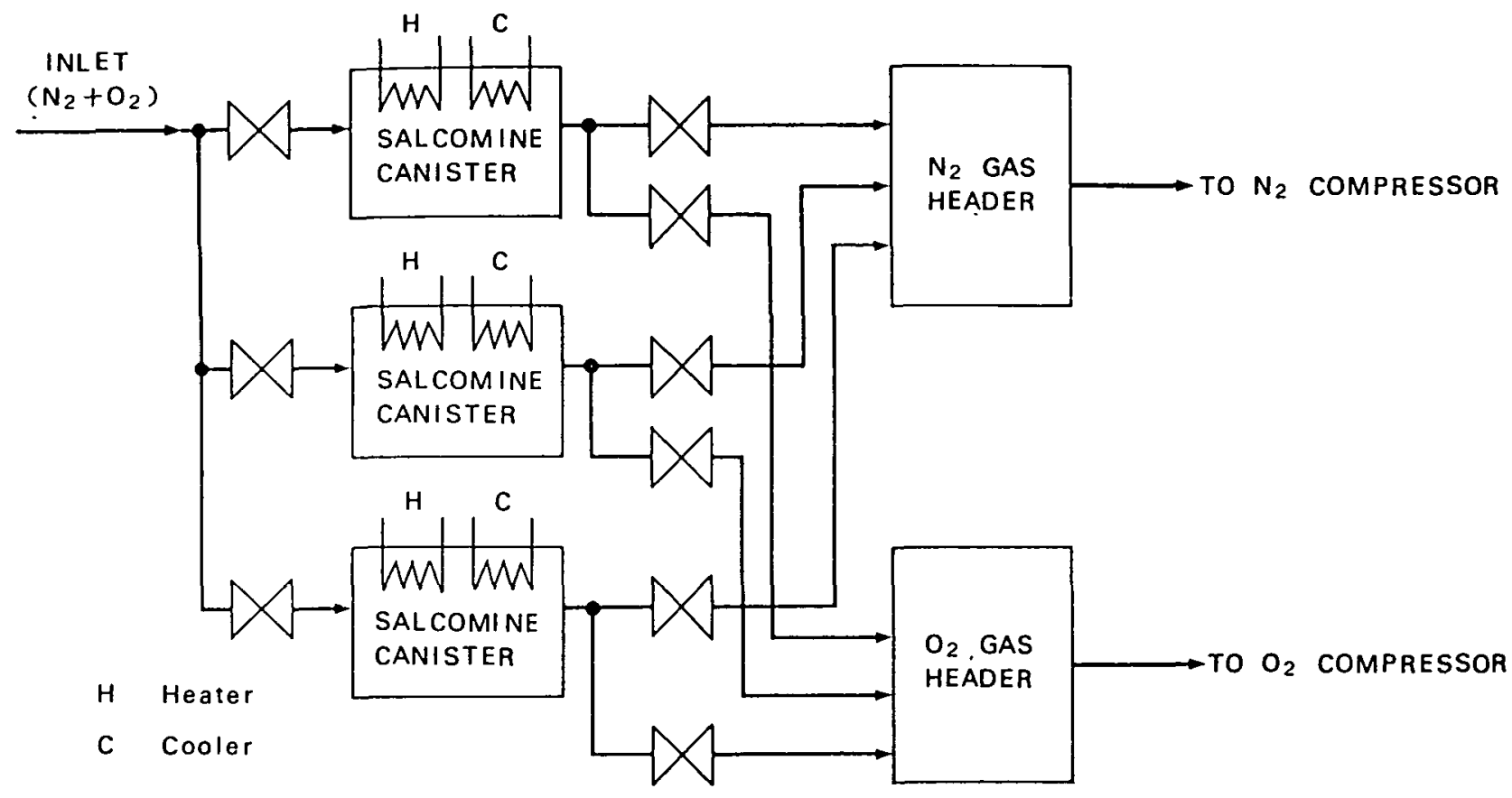

Fig 6 O2 SEPARATING AND CONCENTRATING SYSTEM DIAGRAM

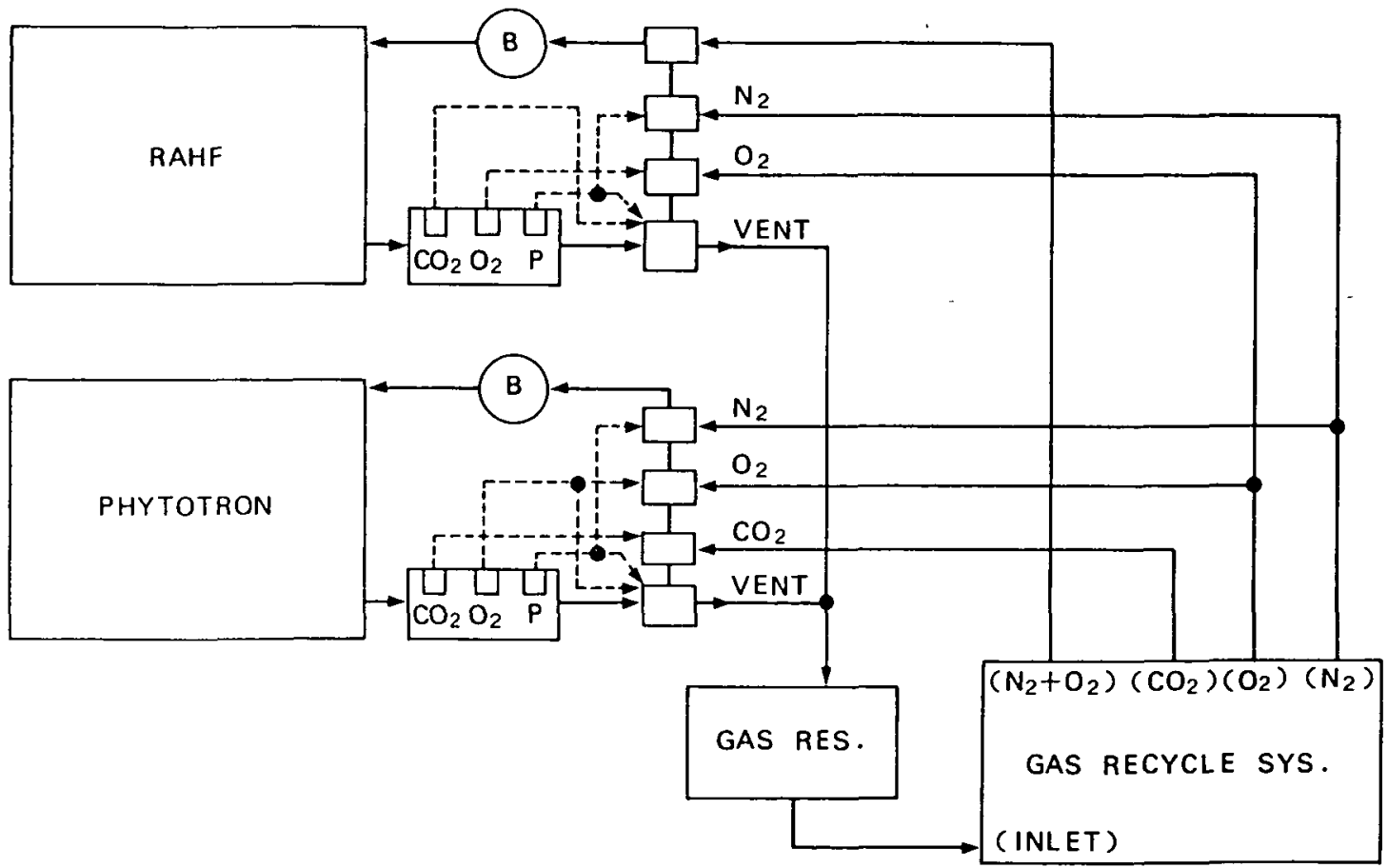

Fig 7 GAS RECYCLE SYSTEM APPLIED TO RAHF AND PHYTOTRON 
According to the measurements of the $\mathrm{pO}_{2}$ (partial pressure of $\mathrm{O}_{2}$ ) and $\mathrm{pCO}_{2}$ (partial pressure of $\mathrm{CO}_{2}$ ) inside the RAHF the $\mathrm{O}_{2}$ supply and gas venting is controlled.

The deviation of the total pressure (P) is compensated by the $\mathrm{N}_{2}$ gas supply or gas discharging from the RAHF.

To the Phytotron, $\mathrm{CO}_{2}$ is supplied from Gas Recycle System and the gas containing 0 is also taken out by mean of the gas ventilator and this gas is again mixed with the gas from the RAHF and sent to the Gas Recycle System.

$\mathrm{CO}_{2}$ supply is necessary to compensate the $\mathrm{pCO}_{2}$ decrease caused by the photosynthetic reaction of plants.

The total pressure and the partial pressures are also controlled similar to the case of RAHF.

\section{PRELIMINARY RESULTS OF DESIGN}

The Gas Recycle System mentioned here comes from the design concept of carbon dioxide reduction system in the cabin for supporting human respiration. It may be possible to be able to improve the system for reducing power consumption. However the more detailed studies on the phytotron, the RAHF and so on will become necessary for this improvement .

\subsection{Requirements}

The design goal of this Gas Recycle System capability has been temporally given as shown in section 4. Namely this Gas Recycle System should manage $925 \mathrm{~g} /$ day of Oxygen and $1,130 \mathrm{~g} /$ day of carbon dioxide corresponding to
$30 \mathrm{lit./hr}$. of $\mathrm{O}_{2}$ and $25 \mathrm{lit./ \textrm {hr }}$. of $\mathrm{CO}_{2}$. The operational pressure of the gas bottles is about $10 \mathrm{kgt} / \mathrm{cm}^{2} \mathrm{G}$.

For saving the gas compression energy, the lower pressure is better, but for making the compact design of system the appropriate high pressure such as $10 \mathrm{kgt} / \mathrm{cm}^{2} \mathrm{G}$ is required.

Table 3 shows these requirements.

8.2 Gas Recycle System Block Diagran

Fig. 8 shows the Gas Recycle System Block diagram.

Inlet gas of $3,600 \mathrm{lit./hr}$. is drawn by the blower. At the filter containing activated chacoal and Hophalite (Carbonmonoxide (CO) oxiding catalyzer), the contaminants such as $\mathrm{CO}$, odor and particles are removed.

At the $\mathrm{CO}_{2}$ concentrater of Solid Amine

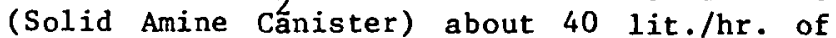
$\mathrm{CO}_{2}$ is obtained, and compressed to the pressure of $10 \mathrm{kgt} / \mathrm{cm}^{2} \mathrm{G}$ and stored into the $\mathrm{CO}_{2}$ gas bottles.

$3,3601 \mathrm{it} . / \mathrm{hr}$. of the outlet gas $\left(\mathrm{CO}_{2}\right.$ lean) returns to the cabine atmosphere. The residual flow of $200 \mathrm{lit} / \mathrm{hr}$. is led to the next process, Salcomine $0_{2}$ concentration.

At the Salcomine $0_{2}$ concentrator (Salcomine Canister), about $40^{2}$ lit./hr. of $0_{2}$ is obtained and is compressed to the pressure of $10 \mathrm{kgt} / \mathrm{cm}^{2} \mathrm{G}$ and stored into the $\mathrm{O}_{2}$ gas bottles.

The residual flow, $160 \mathrm{lit} . / \mathrm{hr}$, of $\mathrm{N}$ gas is compressed to the $10 \mathrm{kgt} / \mathrm{cm}^{2} \mathrm{G}$ and stored into the $\mathrm{N}_{2}$ gas bottles.

8.3 Gas Recycle System Configuration

Table 4 shows the list of principal components of the Gas Recycle System.

Table 3 GAS RECYCLE SYSTEM REQUIREMENTS

\begin{tabular}{lcll}
\hline No. Item & Unit & Value & Remarks \\
\hline $\begin{array}{l}\text { Flow Rate } \\
\text { Oxygen } \\
\text { Carbon dioxide }\end{array}$ & $1 / \mathrm{h}$ & 30 & for one man \\
& $1 / \mathrm{h}$ & 25 & Life Support
\end{tabular}

2. Purity

$\begin{array}{lll}\text { Oxygen } & \% & \text { above } 90 \\ \text { Carbon dioxide } & \% & \text { about } 90 \\ \text { Nitrogen } & \% & \text { about } 90\end{array}$

3. Operating Pressure $\mathrm{kgt} / \mathrm{cm}^{2} \mathrm{G}$ 


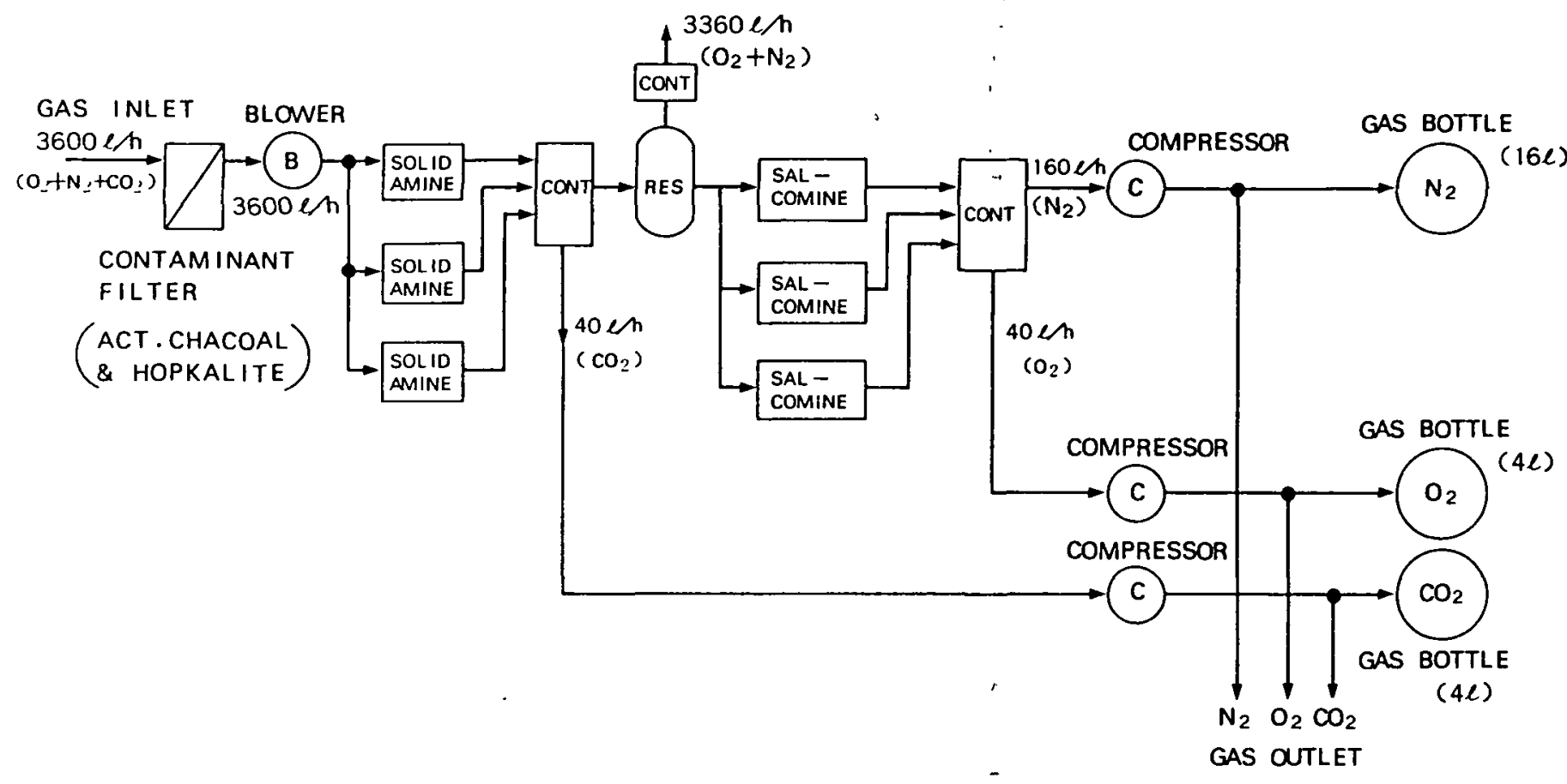

Fig 8 GAS RECYCLE SYSTEM BLOCK DIAGRAM

Table 4 GAS RECYCLE SYSTEM COMPONENTS LIST

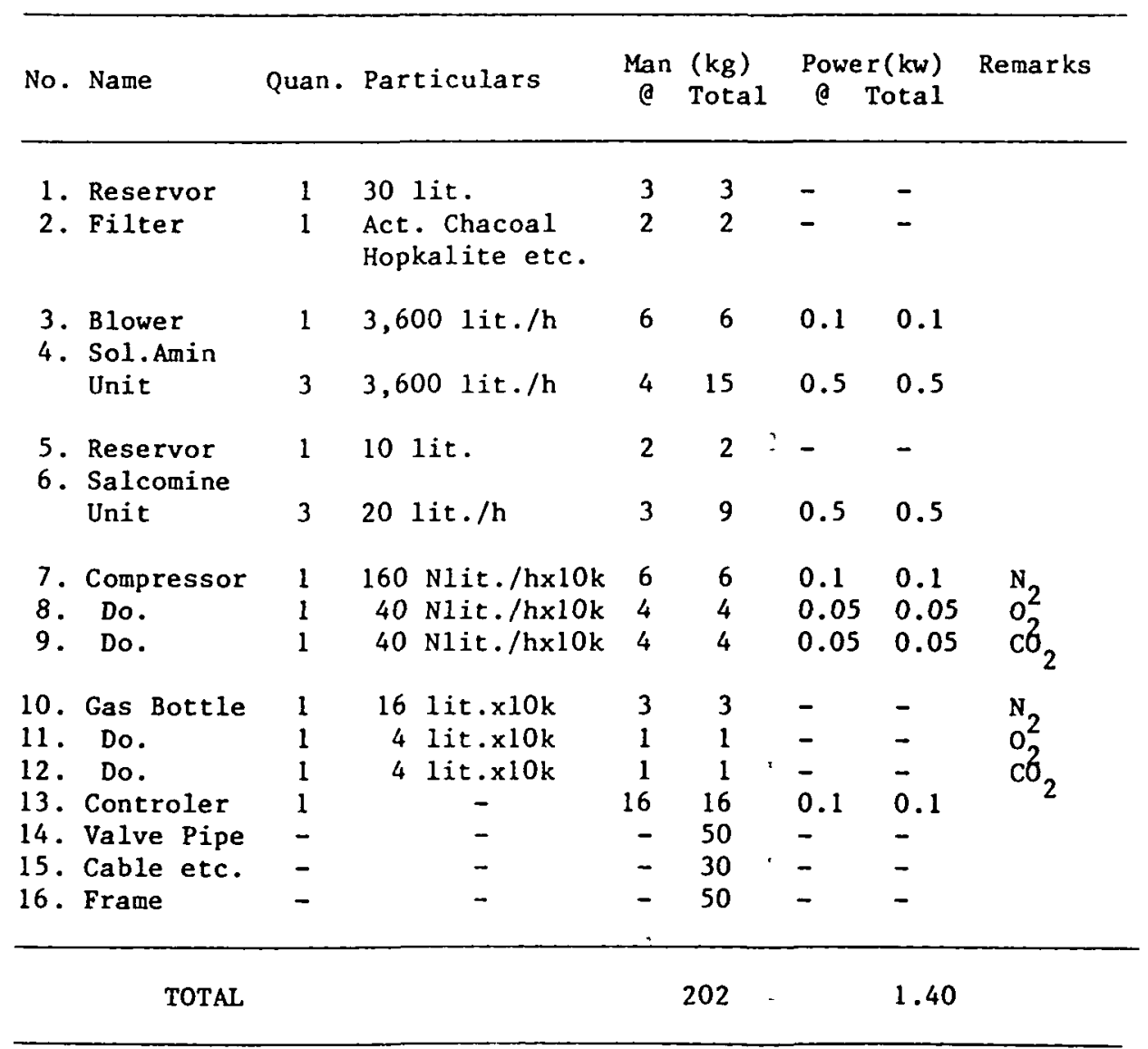


The total mass of this system and the electric power consumption are estimated about $202 \mathrm{~kg}$ and about $1.40 \mathrm{kw}$ respectively.

Fig. 9 shows the configuration of the Gas Recycle system. The components of the Gas Recycle System will be assembled within. the space of the Single Rack of the SPACE LAB.

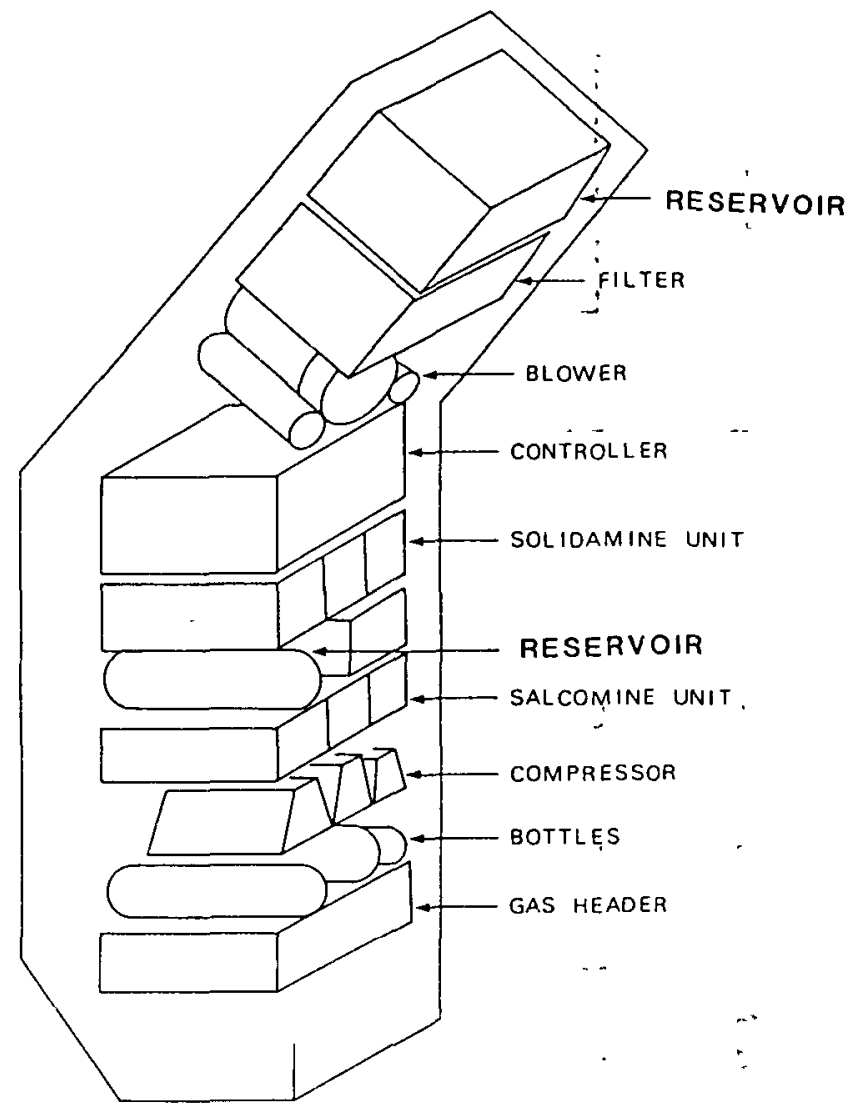

FIg 9 GAS RECYCLE SYSTEM CONFIGURATION

\section{Conclusion}

Through the concept studies for CELSS experiments in Space station, the following results had been obtained.

(1) The guideline of the CELSS technology research and development has been elucidated through the time phase mission sets as the strawman model,

(2) The development feasibility of the various hardware necessary to conduct the CELSS experiments in each time phased mission and the preliminary interface requirements for, each mission sets has been clarified through the concept design studies.

In spite of these fruitful results, many problems to be solved for developing hardware have been found through these studies.

As for the Gas Recycle System, the next two problems seem to be very important for establishing the stability of the system.
(3) The degradation mechanism of $\mathrm{O}_{2}$ absorber agent such as complex salt should be tested and analyzed through bench tests and if the degradation characteristics are not sufficient a more stable agent should be developed.

(4) For establishing complete gas recycle in the CELSS, the balance between the respiration quotient of hetetotroph and the assimulation quotient of autotroph should be established within a definite period of time, the possibility for keeping this balance with the gas recycle system should be tested and checked through ground based experiments, if impossible, the additional equipment for keeping the balance should be introduced as a subsystem in the CELSS hardware.

These studies had been conducted under the support of many researchers belonging to the CELSS research group.

The Authors greatly appreciate their support .

\section{REFERENCES}

1) Keiji NITTA et al, "A concept study on the Japanese Strawman CELSS Experiment Mode1", The Fourteenth International Symposium on Space Technology and Science, Tokyo, May 27 - June 1, 1984.

2) CELSS Experiment Concept Study Group, "CELSS Experiment Concepts of Space Station Missions", MS-SS-02, Rev. 1, April 16, 1984.

3) Keiji NITTA and Masamichi Yamashita, "Concept Study on the Technology of CELSS", IAF-84167, 35th IAF Congress, Switzerland, October 7-13, 1984.

4) Mamoru Matsuda et al, "Development of Diff usive Atmosphere Control System (DACS)", The 3rd International Ocean Development Conference, Tokyo, August 5-8, 1975 .

5) Luskus, L.J. and H.J. Killian, "Breathing Oxygen, Purity of Oxygen Generated by a Fluomine-based system", SAM-TR-76-25, Books AFB TX, September 1976.

6) R.A. Wynveen, F.H. Shubert and J.D. Powe11, "One-Man Self-Contained $\mathrm{CO}_{2}$ Concentration System" NASA CR 114426, Mar. 1972.

7) R.D. Marsha11, F.H. Shubert, J.N. Carlson, "Electrochemical Carbon Dioxide Concentrator", Math Mode1, NASA CR-114639 August, 1973.

8) J.C. Huddleston and Dr. J.R. Aylward, "Hydrogen Depolarized Carbon Dioxide Concentrator Performance Improvements and Cell Pair Structual Tests", NASA CR-134159; September 1973.

9) C.E. Verstko, R.K. Forsyth, "A Study of the Sabatier-Methanation Reaction", ASE. 
740933 July 29 - August 1, 1974.

10) J.R. Meyer, "Extraction of Martian Resources for a Manned Resources for a Manned Research Station", J. of British Interplanetary Society Vol. 34 , pp. 285-288, 1981 .

11) G.N. Kieiner, R.J. Cusick, "Development of an Advanced Sabatier $\mathrm{CO}_{2}$ Reduction Subsystem", ASME '81-ENAs-11, 1981 .

12) Albert $M$. Boem and Robert J. Cusick, "A Regenerable Solid Amine $\mathrm{CO}_{2}$ Concentrator for Space Station", $\mathrm{SAE}^{2} 820847$, July 19-21, 1982.

13) F.H. Samonski, Jr. and H.F. Brose, "A Regenerable $\mathrm{CO}_{2}$ and Humidity Control System for Extended Duration Orbiter Missions", ESA SP-139, November 1978.

14) D.B. Heppner and P.L. Quattrone, "Nitrogen Supply System Based on Hydrozine Dissociation", ASME 81-ENA, $-27,1981$.

15) Walton L. Jones, M.D. and A.L. Irgelfinger, "Atmospheric Control", pp. 807-845, Bioastronautics Data Book, NASA SP-3006, 1973.

16) "Zirconia Oxygen Pump", Toray Co.

17) S.H. Davis et a1, " $\mathrm{CO}_{2}$ and Humidity Removal System for Extended Shuttle Missions, $\mathrm{CO}_{2}, \mathrm{H}_{2} \mathrm{O}$, and Trace Contaminant Equibrium Testing", ASME 77-ENAs-4 (1978).

18) R.J. Lunde et a1, "Development of a Desiccant $\mathrm{CO}_{2}$ Adsorbent Tailored for Shuttle Application", ASME 72-ENAv-11 (1972).

\section{APPEND IX}

\section{Tables}

1 Proposed Theme at the First Japanese Space Station Simposium

2 The Proposed Research Items and the Necessary Time Span for Hardware Development

3 Gas Recycle System Requirements

4 Components List of Gas Recycle System

\section{Figures}

1 CELSS Concept

2 Experiment Architecture of Each Mission

3 Gas Recycle System Functional Diagram

$4 \mathrm{CO}_{2}$ Separating and Concentrating System Diăgram

5 Structure of Salcomine

$6 \mathrm{O}_{2}$ Separating and Concentrating System Diagram

7 Gas Recycle System Applided to RAHF and Phytotron

8 Gas Recycle System Block Diagram

9 Conceptual Configuration of Gas Recycle Sys tem 